K. N. Toraiev ${ }^{1}$, A. S. Nemchenko ${ }^{1}$, N. A. Tsubanova ${ }^{1}$, O. M. Bezchasniuk ${ }^{1}$, L. V. Yevsieieva ${ }^{2}$

${ }^{1}$ National University of Pharmacy

${ }^{2}$ PO "Social and Environmental Safety", Kharkiv

\title{
Substantiation of the choice of components for a combined drug used for the treatment of type 2 diabetes mellitus
}

Diabetes mellitus (DM) is one of the most common non-communicable diseases in the world. As evidenced by the UN resolution, DM is recognized as one of the most threatening diseases in the world. At present there are more than 382 million people with DM. In the EU almost 4-6\% of the population suffers from type 2 diabetes mellitus (DM 2). It should be noted that this disease occurs with an extremely high risk of complications, which lead to disability, morbidity and mortality of patients in this category.

Aim. To substantiate the choice of components for introduction of a combined drug used for the treatment of DM 2.

Materials and methods. The results of meta-analyses concerning medical information of the drug use when treating DM 2 were analyzed.

Results and discussion. The results of the comparative studies of antidiabetic drugs were generalized; the expediency and rationality of the use of metformin as a drug with the proven efficacy and safety when treating DM 2 was revealed.

Conclusions. The authors have proposed and substantiated the effectiveness of a new antidiabetic composition with two API: metformin $(400 \mathrm{mg})$ and benfotiamine $(20 \mathrm{mg})$. The new composition with metformin and benfotiamine has been confirmed by the pharmacological studies as a highly effective antidiabetic agent with a pronounced antioxidant effect and the ability to restore cellular energy deficiency.

Key words: combined antidiabetic drug; metformin; benfotiamine; algorithm of the primary development; pharmacological studies

К. Н. Тораєв, А. С. Немченко, Н. А. Цубанова, О. М. Безчаснюк, Л. В. Євсєєва

Обґрунтування вибору компонентів комбінованого лікарського засобу для лікування ЦД2

Цукровий діабет (ЦД) є одним з найбільш поширених неінфекційних захворювань у світі. Як свідчить резолюція ООН, ЦД визнано однією з найбільш загрозливих хвороб у світі. На сьогодні зареєстровано понад 382 млн осіб, що хворіють на ЦД. У країнах ЄС майже 4-6 \% населення страждають на ЦД 2 типу. Слід зауважити, що дане захворювання відзначається надзвичайно високим ризиком розвитку ускладнень, які призводять до втрати працездатності, інвалідизації та смертності хворих цієї категорії.

Метою роботи $є$ обґрунтування вибору компонентів для впровадження нового комбінованого лікарського засобу для лікування ЦД2.

Матеріали та методи. Проаналізовані результати мета-аналізів стосовно медичної інформації застосування препаратів у лікуванні ЦД2.

Результати та їх обговорення. Узагальнені результати порівняльних досліджень гіпоглікемічних препаратів, виявлено доцільність та раціональність застосування метформіну як ЛЗ з доведеною ефективністю та безпекою у лікуванні ЦД2.

Висновки. Авторами запропонована та обґрунтована ефективність нової протидіабетичної композиції двох АФІ: метформіну (400 мг) і бенфотіаміну (20 мг). Нова композиція з включенням метформіну та бенфотіаміну підтверджена фрармакологічними дослідженнями як високоефективний антидіабетичний засіб з вираженим антиоксидантним ефектом і здатністю відновлювати клітинний енергодефріцит.

Ключові слова: протидіабетичний комбінований лікарський засіб; меторормін; бенфотіамін; алгоритм первинної розробки; фрармакологічні дослідження

К. Н. Тораев, А. С. Немченко, Н. А. Цубанова, О. М. Безчаснюк, Л. В. Евсеева

Обоснование выбора компонентов комбинированного лекарственного средства для лечения СД 2

Сахарный диабет (СД) является одним из наиболее распространенных неинфекционных заболеваний в мире. Как свидетельствует резолюция ООН, СД признан одной из самых угрожающих болезней в мире. На сегодня зарегистрировано более 382 млн человек, страдающих СД. В странах ЕС почти 4-6\% населения страдают СД 2 типа. Следует отметить, что данное заболевание протекает с чрезвычайно высоким риском развития осложнений, которые приводят к потере трудоспособности, инвалидизации и смертности больных этой категории.

Целью работы было обоснование выбора компонентов для внедрения нового комбинированного лекарственного средства для лечения СД2. 
Материалы и методы. Проанализированы результаты мета-анализов по медицинской информации применения препаратов в лечении СД2.

Результаты и их обсуждение. Обобщены результаты сравнительных исследований противодиабетических препаратов, выявлена целесообразность и рациональность применения метформина как ЛС с доказанной эффективностью и безопасностью в лечении СД 2.

Выводы. Авторами предложена и обоснована эфффективность новой противодиабетической композиции двух АФИ: метформина (400 мг) и бенфотиамина (20 мг). Новая композиция с включением метформина и бенфотиамина подтверждена фрармакологическими исследованиями как высокоэффективное антидиабетическое средство с выраженным антиоксидантным эффектом и способностью восстанавливать клеточный энергодефицит.

Ключевые слова: противодиабетическое комбинированное лекарственное средство; метформин; бенфотиамин; алгоритм первичной разработки; фрармакологические исследования

According to the State Statistics Service of Ukraine, diabetes mellitus (DM) ranks third in prevalence after cardiovascular diseases and cancer. Today $2.9 \%$ of the country's total population (or 1198047 patients) have a confirmed diagnosis of diabetes; patients with type 2 diabetes (DM 2) are $90 \%$ of them. Taking into account the high prevalence, the annual growth of the incidence and severe consequences of the disease the introduction of a new domestic combined drug for the treatment of DM 2 is of immediate interest.

The assessment of expediency and feasibility for creating drugs has shown that drugs for treating DM 2 have a wide target segment of the market and the target consumer. DM is the metabolic disorder of the multiple etiology characterized by chronic hyperglycemia with the impaired metabolism of carbohydrates, fats and proteins as a result of abnormalities in insulin secretion or the action of insulin [1-2]. The consequences of diabetes are long-term dysfunctions and failure of various organs. Since this disease is a multi-organ disease, i.e. involving many organs and systems of the body in the pathological process, and it is chronic, its therapy requires a comprehensive approach taking into account the main elements of the pathogenesis of the disease and minimizing associated complications [3].

The incidence of DM 2 increases with age. Additional risk factors associated with age are the presence of chronic pathological processes on the background of reduced compensation abilities of the body. All these facts require special attention to possible manifestations of adverse effects of drug therapy. One of the approaches for solving such problems is the adequate complex therapy, which main criteria are:

- decrease of the drug load on the body (for example, reducing the concentration of the API in a dosage form);

- the use of possibilities of systemic effects of one drug for simultaneous correction of the disturbed functions of several organs or systems;

- the use of additional therapy to prevent potential side and other negative effects.

\section{Materials and Methods}

The general scheme (algorithm) developed to create a combined drug on the basis of the known API consists of 5 stages: the assessment of expediency and feasibility for creating drugs; development of the profile for the future target product; development of the basic concept of the drug; the proof of the drug concept; optimization (correction) of the concept and the approval of the drug model [4].

An important source of information to determine the efficiency and safety of antihyperglycemic therapy is the results of the meta-analysis of large samples of medical information. Therefore, summarizing the results of comparative studies of hypoglycemic drugs, metformin is currently the drug with the most proven efficiency and safety for treating DM 2 [5-10].

Nowadays benfotiamine is considered to be the drug of the first choice for preventing the progression of neuropathy [11]. Numerous works of domestic and foreign researchers confirm the effectiveness of using drugs of benfotiamine for the treatment and prevention of diabetic polyneuropathy [12]. The experimental study by $\mathrm{H}$. Hammes et al. demonstrates that benfotiamine blocks the basic mechanisms of the cellular pathology in hyperglycemia and prevents development of retinopathy [13]. When using benfotiamine it has been shown experimentally that there is a decrease of the oxidative stress in the cerebral cortex of the laboratory animals and the left ventricular myocardium, and improvement of the myocardial contractility [14].

\section{Results and Discussion}

Currently, there are several main categories of hypoglycemic drugs used for treating DM 2, they act on the different stages of the biochemical processes in the body and have different side effects (Tab. 1) [1, 15-17].

The optimal hypoglycemic drug must meet certain requirements:

- the effectiveness in reducing glucose levels in the blood;

- the minimal risk of hypoglycemia;

- the absence of cardiotoxicity, nephrotoxicity, hepatotoxicity;

- the ease of use.

Since 2005 metformin is the first-line drug of pharmacological intervention in DM 2 in the recommendations of the International Diabetes Federation (IDF), since 2006 it is the first-line drug together with non-pharmacological treatment of DM 2 within the framework of the recommendations of the American and the European Associations of diabetologists (ADA и EASD). Since 2007 metformin is the only drug in preventing development of DM 2 in the ADA recommendations [3; 18]. 
Characteristics of the main categories of hypoglycemic drugs used for the treatment of DM 2

\begin{tabular}{|c|c|c|c|}
\hline The drug category & $\begin{array}{c}\text { The name } \\
\text { of API }\end{array}$ & The effect on the pathogenesis of DM & Side effects and other disadvantages \\
\hline $\begin{array}{l}\text { Derivatives of } \\
\text { sulfonyl-urea }\end{array}$ & \begin{tabular}{|l|} 
Gliclazidum \\
Gliquidone \\
Glipizide \\
Glimepiride \\
Glibenclamide
\end{tabular} & $\begin{array}{l}\text { Stimulation of the insulin secretion, } \\
\text { increase of the sensitivity of insulin } \\
\text { receptors }\end{array}$ & $\begin{array}{l}\text { The risk of hypoglycemia, } \\
\text { the weight gain }\end{array}$ \\
\hline Meglitinides & $\begin{array}{l}\text { Repaglinide } \\
\text { Nateglinide }\end{array}$ & Stimulation of the insulin secretion & $\begin{array}{l}\text { The risk of hypoglycemia, } \\
\text { the weight gain }\end{array}$ \\
\hline Biguanides & Metformin & $\begin{array}{l}\text { Inhibition of glucose production by } \\
\text { the liver, increase of the cell resistance } \\
\text { to insulin. Decrease of the metabolic } \\
\text { syndrome symptoms }\end{array}$ & $\begin{array}{l}\text { Gastrointestinal side effects, lactic } \\
\text { acidosis (in the presence } \\
\text { of severe renal failure) }\end{array}$ \\
\hline Thiazolidinediones & $\begin{array}{l}\text { Pioglitazone } \\
\text { Rosiglitazone }\end{array}$ & $\begin{array}{l}\text { Selective activation of PPAR-gamma } \\
\text { receptors, transcription modulation of } \\
\text { genes sensitive to insulin involved in } \\
\text { controlling the glucose level and lipid } \\
\text { metabolism }\end{array}$ & $\begin{array}{l}\text { Water retention, the weight gain. They } \\
\text { can not be used in patients } \\
\text { with heart failure }\end{array}$ \\
\hline $\begin{array}{l}\text { Alpha-glucosidase } \\
\text { inhibitors }\end{array}$ & $\begin{array}{l}\text { Acarbose } \\
\text { Miglitol } \\
\text { Guarem }\end{array}$ & $\begin{array}{l}\text { Competitive inhibition of alpha- } \\
\text { glucosidase. The slower absorption of } \\
\text { certain carbohydrates in the GIT }\end{array}$ & $\begin{array}{l}\text { Gastrointestinal side effects. The need } \\
\text { for repeated administration throughout } \\
\text { the day, the low potential for reducing } \\
\text { glycosylated hemoglobin }\end{array}$ \\
\hline $\begin{array}{l}\text { Incretins: } \\
\text { dipeptidyl } \\
\text { peptidase-IV } \\
\text { inhibitors (DPP-4) }\end{array}$ & $\begin{array}{l}\text { Vildagliptin } \\
\text { Sitagliptin }\end{array}$ & $\begin{array}{l}\text { Increase of the glucose-dependent } \\
\text { insulin secretion and decrease in the } \\
\text { glucagon secretion }\end{array}$ & $\begin{array}{l}\text { The increased risk of respiratory } \\
\text { infections, high cost, insufficient } \\
\text { experience of use }\end{array}$ \\
\hline
\end{tabular}

Metformin has a distinct "window of absorption", moreover, the absorption of metformin in the small intestine is saturating. It means that with the concentration increase of metformin in the intestinal lumen above a certain threshold level there is the absorption saturation [19]. Therefore, the absorption level of metformin from the gastrointestinal tract depends on the evacuation rate of metformin from the stomach. These features determine the complexity of developing tablets of metformin with sustained release that are suitable for taking once a day, and are now popular in research. These peculiarities of metformin pharmacokinetics suggest that a single administration of large doses of the drug (once a day) will be less effective than 2-3 times a day, but in the corresponding smaller doses. At the same time, smaller doses will help to reduce the side effects of the drug [19-20].

The effective daily dose of metformin is in the range from $1200 \mathrm{mg}$ to $2000 \mathrm{mg}$ according to the dose-effect curve [21]. The dose of metformin, in which gastrointestinal side effects are observed, is 400-500 mg. For further studies the variant of $400 \mathrm{mg}$ multiple dose of metformin $(1200 \mathrm{mg} /$ day) was chosen. In our opinion, it appears to be the most optimal from the point of view of both effectiveness and reduction of side effects. A decrease in a single dose and, consequently, a single load on the body reduces the probability of side effects of the drug [19-20].

The possibility of developing the combination of an additional API with metformin for the corrective action on potential side effects of metformin and complications of DM 2 were analyzed. The progression of diabetes leads to development of late complications. In more than $50 \%$ of DM 2 patients macro- and microvascular disorders are observed. Serious damages of nerve endings (neuropathy), capillaries (angiopathy), retino- and nephropathy are the main causes of disability and death in these patients [21-22].

Benfotiamine is an effective drug with a wide range of the therapeutic action; it can prevent development of diabetic polyneuropathy, retinopathy and nephropathy at the early stages, as well as progression of the disease, resulting in the possibility of using benfotiamine in the combined antidiabetic drug.

Thus, a new antidiabetic combination based on metformin and benfotiamine was substantiated. The composition consists of metformin $-72 \mathrm{mg} / \mathrm{kg}$ corresponding to the human daily dose of $1200 \mathrm{mg}$ and benfotiamine $3.6 \mathrm{mg} / \mathrm{kg}$ corresponding to the human daily dose of $60 \mathrm{mg}$. The new composition will allow to reduce side effects of metformin without changing its efficiency, as well as decrease the risk and severity of long-lasting complications of the disease due to the additional corrective treatment with benfotiamine.

In the course of further studies the pharmacological activity of the new composition based on metformin and benfotiamine was determined. The studies of the impact of the new composition based on metformin and benfotiamine on the main indicators of carbohydrate, lipid, 
Dynamics of the body weight growth in rats with dexamethasone-induced diabetes $(n=8)$

\begin{tabular}{|c|c|c|c|c|c|}
\hline \multirow{3}{*}{ No. } & \multirow{3}{*}{ Group } & \multirow{2}{*}{\multicolumn{2}{|c|}{$\begin{array}{l}\text { The body weight, } g \\
\text { The time of the experiment }\end{array}$}} & \multirow{3}{*}{$\begin{array}{c}\text { The dynamics of } \\
\text { the body weight } \\
\text { change }\end{array}$} & \multirow{3}{*}{$\mathrm{p}$} \\
\hline & & & & & \\
\hline & & 1 day & 15 days & & \\
\hline 1 & Intact control & $182 \pm 2.50$ & $194 \pm 2.56$ & $11.9 \pm 0.91$ & - \\
\hline 2 & Control pathology & $184 \pm 2.39$ & $210 \pm 2.31$ & $25.6 \pm 1.47$ & $p_{2-1}<0.001$ \\
\hline 3 & $\begin{array}{l}\text { The composition of metformin }(72 \\
\mathrm{mg} / \mathrm{kg})+ \text { benfotiamine }(3.6 \mathrm{mg} / \mathrm{kg})\end{array}$ & $182 \pm 1.87$ & $196 \pm 1.83$ & $14.4 \pm 1.13$ & $\mathrm{p}_{3-2}<0.001$ \\
\hline 4 & Metformin $(90 \mathrm{mg} / \mathrm{kg})$ & $183 \pm 1.75$ & $197 \pm 2.50$ & $13.7 \pm 1.57$ & $\mathrm{P}_{4-2}<0.001$ \\
\hline
\end{tabular}

and energy metabolism, as well as decrease the lipid peroxidation - antioxidant system (LPO-AO system) were performed under conditions of the experimental DM 2. According to the recommendations, insulin-independent diabetes was modeled by a subcutaneous injection of glucocorticoid dexamethasone in the dose of $0.125 \mathrm{mg} / \mathrm{kg}$ in rats for 14 days with the simultaneous keeping of animals on the high-calorie hydrocarbon diet [23].

In the study 4 groups of animals were used: intact control; control pathology; animals received the composition of metformin in the dose of $72 \mathrm{mg} / \mathrm{kg}$ (corresponding to the human average daily dose of $1200 \mathrm{mg}$ ) and benfotiamine in the dose of $3.6 \mathrm{mg} / \mathrm{kg}$ (corresponding to the human daily dose of $60 \mathrm{mg}$ ) on the background

Table 3

Indicators of the carbohydrate and lipid metabolism in rats on the background of dexamethasone-induced diabetes $(n=8)$

\begin{tabular}{|c|c|c|c|}
\hline $\begin{array}{c}\text { Intact } \\
\text { control }\end{array}$ & $\begin{array}{c}\text { Control } \\
\text { pathology }\end{array}$ & $\begin{array}{c}\text { The } \\
\text { composition } \\
\text { of metformin } \\
(72 \mathrm{mg} / \mathrm{kg})+ \\
\text { benfotiamine } \\
(3.6 \mathrm{mg} / \mathrm{kg})\end{array}$ & $\begin{array}{c}\text { Metformin } \\
(90 \mathrm{mg} / \mathrm{kg})\end{array}$ \\
\hline \multicolumn{4}{|c|}{ Glucose, mmol/L (blood serum) } \\
\hline $5.15 \pm 0.18$ & $11.1 \pm 0.32^{*}$ & $5.65 \pm 0.17^{* *}$ & $5.25 \pm 0.15^{* *}$ \\
\hline \multicolumn{4}{|c|}{ Insulin, pg/ml (blood serum) } \\
\hline $1299 \pm 22.5$ & $2074 \pm 29.8^{*}$ & $1470 \pm 41.6^{* *}$ & $1392 \pm 47.5^{* *}$ \\
\hline \multicolumn{4}{|c|}{ Free fatty acids (FFA), mmol/L (blood serum) } \\
\hline $0.41 \pm 0.04$ & $0.81 \pm 0.04^{*}$ & $0.59 \pm 0.02^{*} / *$ & $0.56 \pm 0.03^{*} / *$ \\
\hline \multicolumn{4}{|c|}{ Triacylglycerols (TAG), mmol/L (blood serum) } \\
\hline $0.83 \pm 0.05$ & $1.89 \pm 0.04^{*}$ & $0.99 \pm 0.06^{* *}$ & $0.89 \pm 0.04^{* *}$ \\
\hline \multicolumn{4}{|c|}{ Cholesterol, mmol/L (blood serum) } \\
\hline $2.17 \pm 0.10$ & $3.47 \pm 0.11^{*}$ & $2.36 \pm 0.09^{* *}$ & $2.22 \pm 0.10^{* *}$ \\
\hline High density lipoproteins (HDL), mmol/L (blood serum) \\
\hline $1.16 \pm 0.05$ & $0.88 \pm 0.03^{*}$ & $1.10 \pm 0.04^{* *}$ & $1.13 \pm 0.04^{* *}$ \\
\hline
\end{tabular}

Notes: * significant deviation of the indicator compared to the intact control group, $\mathrm{p}<0.01$; $^{* *}$ - significant deviation of the indicator compared to the control pathology group, $\mathrm{p}<0.01$. of the experimental pathology; animals received the reference drug metformin in the dose of $90 \mathrm{mg} / \mathrm{kg}$ (corresponding to the human average daily dose of $1500 \mathrm{mg}$ ) on the background of the experimental pathology (Tab. 2-5).

The studies have shown that the new composition in the conditions of insulin-independent diabetes with a high carbohydrate load shows a pronounced antidiabetic activity. Decrease in the daily dose by $20 \%(1200 \mathrm{mg} /$ day vs $1500 \mathrm{mg} /$ day) did not lead to statistically significant deviations in the effectiveness of the antidiabetic action.

By the effect on the main indicators of carbohydrate (glucose, insulin) and lipid (free fatty acids, triacylglycerols, cholesterol, high density lipoproteins) metabolism the new composition is not inferior to the action of the refe-

Table 4

Indicators of the LPO-AO system metabolism in rats on the background of dexamethasone-induced diabetes $(n=8)$

\begin{tabular}{|c|c|c|c|}
\hline $\begin{array}{c}\text { Intact } \\
\text { control }\end{array}$ & $\begin{array}{c}\text { Control } \\
\text { pathology }\end{array}$ & $\begin{array}{c}\text { The } \\
\text { composition } \\
\text { of metformin } \\
(72 \mathrm{mg} / \mathrm{kg})+ \\
\text { benfotiamine } \\
(3.6 \mathrm{mg} / \mathrm{kg})\end{array}$ & $\begin{array}{c}\text { Metformin } \\
(90 \mathrm{mg} / \mathrm{kg})\end{array}$ \\
\hline \multicolumn{4}{|c|}{ TBA-AP, mcmol/L (blood serum) } \\
\hline $1.08 \pm 0.05$ & $2.91 \pm 0.10^{*}$ & $\begin{array}{c}1.84 \pm 0.07 \\
{ }^{* *} / /^{*}\end{array}$ & $2.31 \pm 0.04^{*} / *$ \\
\hline TBA-AP, mcmol/g (liver homogenate) \\
\hline $80.7 \pm 0.90$ & $230 \pm 9.07^{*}$ & $\begin{array}{c}128 \pm 4.84 \\
* / * / * *\end{array}$ & $165 \pm 5.12^{* * *}$ \\
\hline \multicolumn{4}{|c|}{ G-SH, c.u. (liver homogenate) } \\
\hline $66.5 \pm 1.38$ & $30.4 \pm 1.64^{*}$ & $57.7 \pm 2.55^{*} / * *$ & $52.1 \pm 1.19^{*} / *$ \\
\hline \multicolumn{4}{|c|}{ Catalase, $\mu \mathrm{kat} / \mathrm{g}$ (liver homogenate) } \\
\hline $0.37 \pm 0.01$ & $0.20 \pm 0.02^{*}$ & $0.32 \pm 0.01^{*} / * *$ & $0.29 \pm 0.01^{*} / * *$ \\
\hline
\end{tabular}

Notes: ${ }^{*}$ - significant deviation of the indicator compared to the intact control group, $\mathrm{p}<0.01$; $^{* *}$ - significant deviation of the indicator compared to the control pathology group, $\mathrm{p}<0.01$; *** significant deviation of the indicator compared to the group that received metformin, $\mathrm{p}<0.01$. 
Indicators of the energy metabolism in rats on the background of dexamethasone-induced diabetes $(\mathrm{n}=8)$

\begin{tabular}{|c|c|c|c|}
\hline Intact control & Control pathology & $\begin{array}{c}\text { The composition of } \\
\text { metformin }(72 \mathrm{mg} / \mathrm{kg})+ \\
\text { benfotiamine }(3.6 \mathrm{mg} / \mathrm{kg})\end{array}$ & Metformin $(90 \mathrm{mg} / \mathrm{kg})$ \\
\hline \multicolumn{4}{|c|}{ ATP, $\mathrm{mcmol} / \mathrm{g}$ (brain homogenate) } \\
\hline $3.02 \pm 0.06$ & $1.25 \pm 0.05^{*}$ & $2.62 \pm 0.04^{* / * * * * * *}$ & $2.11 \pm 0.05^{*} / * *$ \\
\hline \multicolumn{4}{|c|}{ ADP, mcmol/g (brain homogenate) } \\
\hline $0.273 \pm 0.005$ & $0.333 \pm 0.007^{*}$ & $0.274 \pm 0.005^{* * * * *}$ & $0.304 \pm 0.005^{*} / * *$ \\
\hline \multicolumn{4}{|c|}{ Citrate synthase, $\mathrm{nmol} / \mathrm{min}, \mathrm{mg}$ of protein (brain homogenate) } \\
\hline $4.79 \pm 0.08$ & $2.60 \pm 0.07^{*}$ & $4.29 \pm 0.08 * / * * * * *$ & $3.34 \pm 0.15 * / * *$ \\
\hline \multicolumn{4}{|c|}{ Succinate dehydrogenase $\mathrm{nmol} / \mathrm{min}, \mathrm{mg}$ of protein (brain homogenate) } \\
\hline $7.43 \pm 0.17$ & $2.90 \pm 0.10^{*}$ & $6.80 \pm 0.13^{*} / * * / * * *$ & $4.35 \pm 0.20 * / * *$ \\
\hline \multicolumn{4}{|c|}{ Piruvate dehydrogenase $\mathrm{nmol} / \mathrm{min}, \mathrm{mg}$ of protein (brain homogenate) } \\
\hline $29.6 \pm 0.46$ & $17.3 \pm 0.47^{*}$ & $27.9 \pm 0.57^{* *} / * * *$ & $21.1 \pm 0.41 * / * *$ \\
\hline
\end{tabular}

Notes: ${ }^{*}$ - significant deviation of the indicator compared to the intact control group, $p<0.01$; ** significant deviation of the indicator compared to the control pathology group, $\mathrm{p}<0.01$; $^{* * *}$ - significant deviation of the indicator compared to the group that received metformin, $\mathrm{p}<0.01$.

rence drug metformin in the dose of $90 \mathrm{mg} / \mathrm{kg}$ (corresponding to the human average daily dose of $1500 \mathrm{mg}$ ), moreover, the dose of the reference drug is $20 \%$ higher than the dose of metformin included in the composition.

\section{CONCLUSIONS}

The new composition with metformin and benfotiamine has a pronounced antioxidant action, restores all parameters of the energy metabolism studied (ATP, ADP, citrate synthase, succinate dehydrogenase, piruvate dehydrogenase); moreover, it significantly exceeds the efficiency of the reference drug metformin in the dose of $90 \mathrm{mg} / \mathrm{kg}$.
The new composition with metformin $(72 \mathrm{mg} / \mathrm{kg}$ corresponding to the human daily dose of $1200 \mathrm{mg}$ ) and benfotiamine $(3.6 \mathrm{mg} / \mathrm{kg}$ corresponding to the human daily dose of $60 \mathrm{mg}$ ) has been confirmed by the pharmacological studies as a highly effective antidiabetic agent with a pronounced antioxidant effect and the ability to restore cellular energy deficiency. This composition has a significant advantage compared to the standard treatment regimens that include average therapeutic doses of metformin.

Conflicts of Interest: authors have no conflict of interest to declare.

\section{REFERENCES}

1. Балаболкин, М. И. Лечение сахарного диабета и его осложнений (руководство для врачей) / М. И. Балаболкин, Е. М. Клебанова, В. М. Креминская. - М. : Медицина, 2005. - 511 с.

2. Программа ВОЗ по діабету [Електронний ресурс] // ВО3. - Режим доступу : http://www.who.int/diabetes/ru.

3. Holst, J. J. The physiology and pharmacology of incretins in type 2 diabetes mellitus / Jens J. Holst // Diabetes, Obesity and Metabolism. 2008. - Vol. 10. - P. 14-21. doi : 10.1111/j.1463-1326.2008.00920.x.

4. Розробка алгоритму створення комбінованого лікарського засобу / К. Н. Тораєв, А. С. Немченко, Л. В. Євсєєва, Ю. І. Губін // Управління, економіка та забезпечення якості в фармації. - 2016. - № 3. - С. 9-15.

5. Древаль, А. В. Роль сахароснижающих таблетированных препаратов в лечении сахарного диабета 2 типа / А. В. Древаль, И. В. Мисникова // Рос. мед. журн. - 2005. - Т. 13, № 6. - С. 332-334.

6. Effects of Vildagliptin on Glucose Control Over 24 Weeks in Patients with Type 2 Diabetes Inadequately Controlled with Metformin / E. Bosi, R. P. Camisasca, C. Collober et al. // Diabetes Care. - 2007. - Vol. 30, Issue 4. - P. 890-895. doi : 10.2337/dc06-1732.

7. Dipeptidyl peptidase -4 inhibitors for treatment of type 2 diabetes mellitus in the clinical setting: systematic review and meta-analysis // BMJ. - 2012. doi : 10.1136/bmj.e1369.

8. Even more about diabetes. Dollars and sensible therapeutics [Internet]. - Available at : http://www.slideshare.net/ARHGrandRounds/ abbotsford-feb-26-2014.

9. Mortality and cardiovascular risk associated with different insulin secretagogues compared with metformin in type 2 diabetes, with or without a previous myocardial infarction: a nationwide study / T. K. Schramm, G. H. Gislason, A. Vaag et al. // Eur. Heart J. - 2011. Vol. 32, Issue 15. - P. 1900-1908. doi : 10.1093/eurheartj/ehr077.

10. Comparison between vildagliptin and metformin to sustain reductions in HbAlc over 1 year in drug-naive patients with type 2 diabetes / A. Schweizer [et al.] // Diabet Med. - 2007. - Vol. 24, Issue 9. - P. 955-961. doi : 10.1111/j.1464-5491.2007.02191.x.

11. Діабетичні нейропатії / О. О. Сергієнко, А. С. Єфімов, Д. А. Єфімов, Ю. Я. Кривко ; НАМН України, ЛНМУ ім. Данила Галицького, Інститут ендокринології та ОР ім. В. П. Комісаренка НАМН України. - Львів; К., 2004. - С. $24-45$.

12. Гурьева, И. В. Терапевтические возможности бенфотиамина / И. В. Гурьева // Фарматека. Эндокринология. - 2010. - № 16 (210). - С. 26-30. 
13. Верткин, А. Л. Преимущества бенфотиаминсодержащих препаратов в лечении диабетической полинейропатии / А. Л. Верткин, В. В. Городецкий // Фарматека. - 2005. - № 10.- С. 1-6.

14. Benfotiamine blocks three major pathways of hyperglycemic damage and prevents experimental diabetic retinopathy / H. P. Hammes, X. Du, D. Edelstein et al. // Nature Med. - 2003. - Vol. 9. - P. 1-6.

15. Майоров, А. Ю. Современные сахароснижающие средства в лечении сахарного диабета 2 типа / А. Ю. Майоров, И. В. Науменкова // Рус. мед. журн. - 2001. - Т. 9, № 24. - С. 1105-1111.

16. Эндокринология: национальное руководство / под ред. И. И. Дедова, Г. А. Мельниченко. - М. : ГЭОТАР-Медиа, 2012. - 1072 с.

17. Зилов, А. В. Метформин - 50 лет в клинической практике / А. В. Зилов, А. Л. Терехова // Лечащий врач. - 2008. - № 3. - С. 15-39.

18. Larson, N. F. Metformin More Effective if Initiated Soon After Diabetes Diagnosis / N. F. Larson // Diabetes Care. - 2010. - P. 501-506.

19. Доклінічні дослідження лікарських засобів : метод. рек. / за ред. О. В. Стефанова. - К. : Авіценна, 2001. - С. $396-404$.

20. Грицюк, М. І. Порівняльна характеристика експериментальних моделей цукрового діабету / М. І. Грицюк, Т. М. Бойчук, О. І. Петришев // Світ медицини та біології. - 2014. - № 2 (44). - С. 199-203.

21. Мкртумян, А. М. Метформин с пролонгированным высвобождением (Глюкофаж Лонг) - высокоэффективный и безопасный препарат первой линии в лечении сахарного диабета 2 типа / А. М. Мкртумян // Рус. мед. журн. Эндокринол. - 2011. - № 13. C. 838. - Режим доступу : http://www.rmj.ru/articles_7735.htm.

22. Riddle, M. C. Combined Therapy with Insulin Plus Oral Agents. Is there Any Advantage [Internet] / M. C. Riddle. - Available at : http:/ www.codhy.com/berlin/Uploads/assets/pptriddel.pdf

23. High-dose benfotiamine rescues cardiomyocyte contractile dysfunction in streptozotocin-induced diabetes mellitus / A. F. Ceylan-Isik, S. Wu, Q. Li et al. // J. Appl. Phisiol. - 2006. - Vol. 100, Issue 1. - P. 150-156. doi : 10.1152/japplphysiol.00988.2005.

\section{REFERENCES}

1. Balabolkin, M. I., Klebanov, E. M., Kreminskaya, V. M. (2005). Lechenie sakharnogo diabeta i ego oslozhnenii ( rukovodstvo dlia vrachei). Moscow: Medicine, 511.

2. Programma VOZ po diabetu. Available at: www.who.int/diabetes/ru.

3. Holst, J. J. (2008). The physiology and pharmacology of incretins in type 2 diabetes mellitus. Diabetes, Obesity and Metabolism, 10, 14-21. doi: 10.1111/j.1463-1326.2008.00920.x.

4. Toraiev, K. N., Nemchenko, A. S., Yevsieieva, L. V., Hubin, Yu. I. (2016). Upravlinnia, economika ta zabezpechennia yakosti v farmatsii, 3, 9-15.

5. Dreval, A. V., Misnikova, I. V. (2005). Russkii meditcinskii zhurnal, 13 (6), 332-334.

6. Bosi, E., Camisasca, R. P., Collober, C., Rochotte, E., Garber, A. J. (2007). Effects of Vildagliptin on Glucose Control Over 24 Weeks in Patients With Type 2 Diabetes Inadequately Controlled With Metformin. Diabetes Care, 30 (4), 890-895. doi: 10.2337/dc06-1732.

7. Dipeptidyl peptidase- 4 inhibitors for treatment of type 2 diabetes mellitus in the clinical setting: systematic review and meta-analysis (2012). BMJ. doi: 10.1136/bmj.e1369.

8. Even more about diabetes. Dollars and sensible therapeutics. Available at: http://www.slideshare.net/ARHGrandRounds/abbotsfordfeb-26-2014.

9. Schramm, T. K., Gislason, G. H., Vaag, A., Rasmussen, J. N., Folke, F., Hansen, M. L., Torp-Pedersen, C. (2011). Mortality and cardiovascular risk associated with different insulin secretagogues compared with metformin in type 2 diabetes, with or without a previous myocardial infarction: a nationwide study. European Heart Journal, 32 (15), 1900-1908. doi: 10.1093/eurheartj/ehr077.

10. Schweizer, A., Couturier, A., Foley, J. E., Dejager, S. (2007). Comparison between vildagliptin and metformin to sustain reductions in HbAlcover 1 year in drug-naïve patients with Type 2 diabetes. Diabetic Medicine, 24 (9), 955-961. doi: 10.1111/j.1464-5491.2007.02191.x.

11. Serhiienko, O. O., Yefimov, A. S., Yefimov, D. A., Kryvko, Yu. Ya. (2004). Diabetichni neiropatii. Lviv; Kyiv, 24-45.

12. Gureva, I. V. (2010). Farmateka. Endokrinologia, 16 (210), 26-30.

13. Vertkin, A. L., Gorodetskyi, V. V. (2005). Farmateka, 10, 1-6.

14. Hammes, H. P., Du, X., Edelstein, D. et al. (2003). Benfotiamine blocks three major pathways of hyperglycemic damage and prevents experimental diabetic retinopathy. Nature Med, 9, 1-6.

15. Maiorov, A. Yu., Naumenkova, I. V. (2001). Russkii meditcinskii zhurnal, 9 (24), 1105-1111.

16. Dedov, I., Melnichenko, H. A. (2012). Endokrinologiia: natcionalnoe rukovodstvo. Moscow: GEOTAR-Media, 1072.

17. Zilov, A. V., Terekhova A. L. (2008). Lechashchii vrach, 3, 15-39.

18. Larson, N. F. (2010). Metformin More Effective if Initiated Soon After Diabetes Diagnosis. Diabetes Care, 501-506.

19. Stefanova, A. V. (2001). Doclinichni doslidzhennia likarskikh zasobiv. Kyiv: Avicenna, 396-404.

20. Hrytsiuk, M. I., Boihuk, T. M., Petryshev, A. I. (2014). Svit medytsyny ta bilogii, 2 (44), 199-203.

21. Mkrtumian, A. M. (2011). Russkii meditcinskii zhurnal. Endokrinolohiia, 13, 838. Available at: http://www.rmj.ru/articles_7735.htm.

22. Riddle, M. C. Combined Therapy with Insulin Plus Oral Agents. Is there Any Advantage. Available at: http://www.codhy.com/berlin/ Uploads/assets/pptriddel.pdf.

23. Ceylan-Isik, A. F. (2006). High-dose benfotiamine rescues cardiomyocyte contractile dysfunction in streptozotocin-induced diabetes mellitus. Journal of Applied Physiology, 100 (1), 150-156. doi: 10.1152/japplphysiol.00988.2005. 
Information about authors:

Nemchenko A. S., Doctor of Pharmacy (Dr. habil.), professor, head of the Department of Organization and Economics of Pharmacy, National University of Pharmacy Tsubanova N. A., Doctor of Pharmacy (Dr. habil.), professor of the Department of General Pharmacy and Drug Safety, Institute for Continuing Education of Pharmacy Professionals at the National University of Pharmacy. E-mail: farmtex-ipksf@nuph.edu.ua

Bezchasniuk O. M., Cand. of Pharmacy (Ph. D.), associate professor of the Quality Management Department, National University of Pharmacy.

E-mail: eluat@yandex.ua

Toraiev K. N., postgraduate student of the Department of Organization and Economics of Pharmacy, National University of Pharmacy

Yevsieieva L. V., head of PO "Social and Environmental Safety". E-mail: lar0858@gmail.com

Відомості про авторів

Немченко А. С., Д-р фарм. наук, професор, завідувач кафедри організації та економіки фармації, Національний фармацевтичний університет Цубанова Н. А., д-р фарм. наук, професор кафедри загальної фармації та безпеки ліків ІПКСФ, Національний фармацевтичний університет. E-mail: farmtex-ipksf@nuph.edu.ua

Безчаснюк О. М., канд. фарм. наук, доцент кафедри управління якістю, Національний фармацевтичний університет. E-mail: eluat@уаndex.ua Тораєв К. Н., аспірант, Національний фармацевтичний університет

Євсєєва Л. В., керівник Громадської організації «Соціальна та екологічна безпека». E-mail: lar0858@gmail.com

Сведения об авторах:

Немченко А. С., д-р фарм. наук, профессор, заведующая кафедрой организации и экономики фармации, Национальный фармацевтический университет Цубанова Н. А., д-р фарм. наук, профессор кафедры общей фармации и безопасности лекарств ИПКСФ, Национальный фармацевтический университет. E-mail: farmtex-ipksf@nuph.edu.ua

Безчаснюк Е. М., канд. фарм. наук, доцент кафедры управления качеством, Национальный фармацевтический университет. Е-таil: eluat@уаndex.uа Тораєв К. Н., аспирант, Национальный фармацевтический университет

Евсеева Л. В., руководитель Общественной организации «Социальная и экологическая безопасность». E-mail: lar0858@gmail.com 